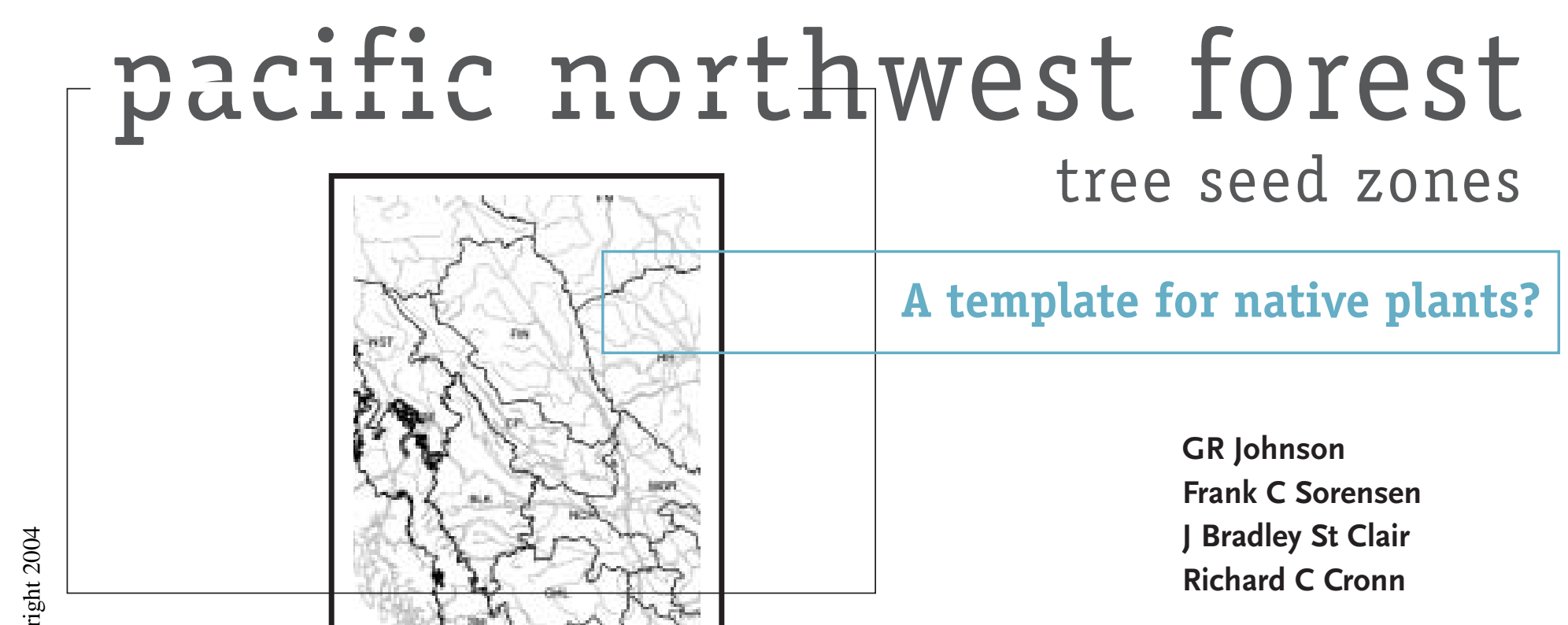

ABSTRACT

Seed movement guidelines for restoration activities are lacking for most native grasses, forbs, and shrubs. The forestry community has decades of experience in establishing seed zones and seed movement guidelines that may be of value to restoration managers. We review the history of seed zone development in forest trees, with emphasis on the Pacific Northwest, and make some suggestions concerning seed transfer guidelines for other native plants.

KEY WORDS seed movement, genetic variation, adaptation

NOM ENCLATURE

ITIS (2002)
1

he forestry community has been restoring, replanting, and reforesting lands with native tree species for decades in North America and for centuries in Europe. This work and early provenance tests show large amounts of source-related genetic variation within species for traits that are associated with adaptation, such as growth traits, cold hardiness, and phenology. As a consequence, the forestry community in the US Pacific Northwest (Oregon and Washington) initiated forest tree seed certification and a system of seed zones in the 1960s. These seed zones have been modified over time to incorporate new research information. Although adaptive variation in forest trees is usually continuous across the landscape, zones with distinct boundaries generally have been used to control seed use for administrative reasons. A seed zone is a mapped area with fixed boundaries in which seeds or plant materials can be transferred with minimal risk of maladaptation and, this is important in forestry, with minimal risk of a loss in productivity. Continuous zones, or seed transfer guidelines, are similar in that they recommend how far seeds can be transferred from point of origin, and describe the relative risk associated with that transfer.

The use of non-timber native plants (grasses, forbs, and shrubs) in restoration and reclamation is increasing, with some concern that seed transfer guidelines of some kind may be needed (Lesica and Allendorf 1999; Booth and Jones 2001; Hufford and Mazer 2003). This concern is reasonable because, in addition to forest trees, both agronomic crops and orna- 
mental releases have recommended limits for their distribution. Our purpose is not to suggest particular guidelines or zones for seed transfer in native plants but to describe the process of developing seed zones as has been done for forest trees with emphasis on the Pacific Northwest. Our intent is to draw attention to the wealth of knowledge gained from decades of forestry research and experience, as well as to stimulate interest and discussion for the development of similar guidelines for grasses, forbs, and shrubs.

\section{THE BEGINNINGS}

In commercial forestry, harvesting meant replanting and promoting the development of the new plantation with the expectation that it would be as, or more, productive than the stand it replaced. With uncontrolled seed transfer, failures occurred, sometimes taking many years to develop even after seemingly successful establishment. Failure was often due to a climatic, insect, or disease event that had much less impact on the native source (if at all).

In European forestry, long-term provenance studies were established over $100 \mathrm{y}$ ago to look at landscape-scale variation in productivity and adaptation for native (Schott 1904; Langlet 1936) and introduced species (Zon 1913). Soon after, provenance tests were started in the US with some of the most important species in the Pacific Northwest (Munger and Morris 1937; Squillace and Silen 1962) and Southeast (Wakeley and Bercaw 1965). The early tests, though important in establishing the magnitude of racial variation, were too wide-ranging for practical application. They contained too few provenances and these provenances were too widely distributed across the species range. From these tests, managers learned there were limits to seed transfer, but they didn't know what those limits were in their region.

Seed zones were delineated in Oregon and Washington in 1966 and revised slightly in 1973 (Tree Seed Zone Map 1973), partly under the impetus of the expanding tree-improvement programs. The zoning was intended primarily for Douglas-fir (Pseudotsuga menziesii [Mirbel] Franco [Pinaceae]) reforestation, but it was also used for other forest tree species. At that time no one realized that different commercial species would have different zone amplitudes. The zones were based primarily on local evaluation of differences in environment, climate, and vegetation and included a general restriction on elevational transfer (approximately $150 \mathrm{~m}$ [500 ft]). As research information became available from common-garden studies and genetic field trials, the seed zones were broadened, redesigned, and made species-specific (Randall 1996; Randall and Berrang 2002). The Great Plains also developed provisional seed zones in the 1970s based on major land resource regions, precipita-

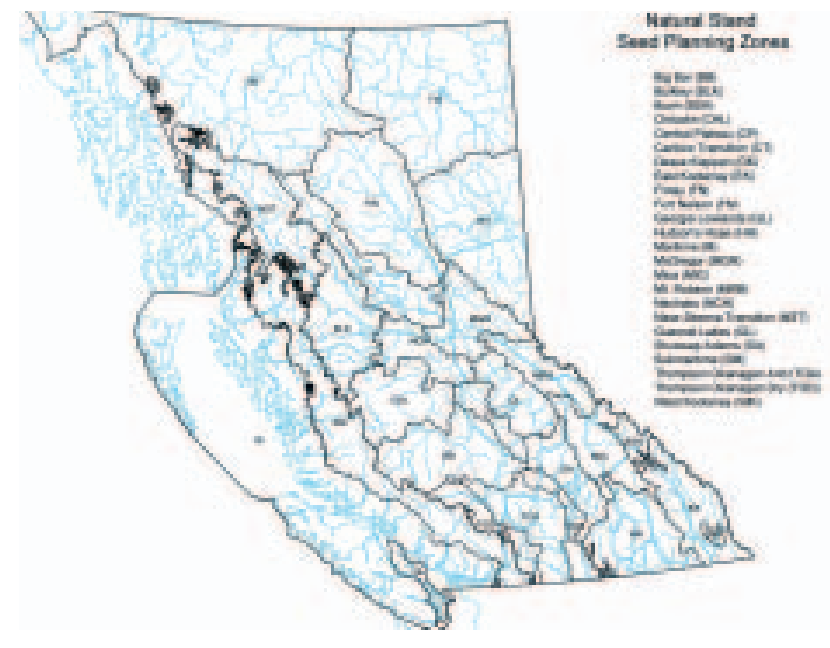

Figure 1. British Columbia's seed planning zones.

Columbia has developed 21 geographic zones (Figure 1; Illingworth and Szalkai 1993) that are modified as new information becomes available. Research in the southeastern US has found that the USDA cold hardiness zones (USDA 1990) work well for the economically important southern pines (Schmidtling 2001).

\section{RESEARCH EXAMINING GENETIC VARIATION} PATTERNS ACROSS THE LANDSCAPE

Since the late 1960s and early 1970s, researchers in British Columbia, the northern Rocky Mountains, California, and the Pacific Northwest have documented the genetic variation patterns of different forest tree species. Four types of studies have provided information on patterns of adaptive genetic variation across the landscape: long-term field provenance trials, medium-term progeny tests, short-term common-garden nursery studies, and molecular markers.

\section{Long-Term Provenance Trials}

Long-term provenance trials test different provenance collections over a variety of planting locations and are analogous to reciprocal transplant studies. Provenance trials should provide the most reliable information for determining the limits of seed movement and discerning which seed sources are best for planting locations because they evaluate seed sources over a long period of time. This long time interval exposes the provenances to the climatic variation experienced in a region-specifically, to extreme climatic events. These trials have disadvantages: they are costly in resources and time. Initially, they included too few and too widely dispersed provenances; adaptive differences were identified, but the pattern of variation couldn't be mapped (for example, Munger and Mor- 
ris 1937; Squillace and Silen 1962; Wakeley and Bercaw 1965). Provenance by plantation interactions, large microsite variation within plantations, and loss or damage to provenances on stress sites often made the results difficult to interpret (White and Ching 1985; Ying 1997). When the species of interest were exotics (Burdon and Low 1991; Kleinschmit and others 1996) or were to be planted beyond their natural range (Xie and Ying 1994), field provenance trials were preferred over short-term nursery trials. Long-term trials also were necessary if the goal was to detect source-related variation in resistance to naturally occurring pests (for example, Read 1971; Read and Sprackling 1981; Ying and Hunt 1987; Hoff 1988).

A key finding emerging from long-term trials is that poorly adapted seed sources typically were not maladapted because they could not tolerate the average conditions of a site, but rather because they did not tolerate the rare climatic events that occurred every 10 or more years. Although this may sound long, it is only a fraction of the life of many forest trees. For example, in a Douglas-fir provenance plantation (Munger and Morris 1937) established in the Oregon Coast Range (Hebo Ranger District, Siuslaw National Forest), all seed sources performed relatively well from 1915 until 1955. In mid-November 1955, the area had an unusual and prolonged cold spell (Duffield 1956). The frost damaged off-site seed sources, killing some trees and causing serious damage to others. In contrast, the local stand suffered damage but continued to grow well (Silen 1995).

\section{Progeny Tests}

The Pacific Northwest has hundreds of progeny tests where open-pollinated families of a species are planted together at multiple sites. Growth data are typically collected in these studies for 10 to $20 \mathrm{y}$. The parents of the progeny are well distributed, and location information on parents is usually available. With the aid of GIS and climatic models, the topographic and climatic variables for the parent location can be estimated. The limitations to these studies are that the area and environmental variation represented by the parent tree locations is generally small, and information on traits other than height and diameter is usually lacking (Silen and Mandel 1983). Information from these trials has demonstrated geographic variation patterns in growth, phenology, and cold hardiness over limited areas (for example, Silen and Mandel 1983; Balduman and others 1999).

\section{Short-term Common-garden Studies}

By far the most common method of mapping genetic variation across the landscape in the Pacific Northwest has been through short-term, common-garden studies in nursery environments (Figure 2). Short-term common-garden studies, compared with field provenance trials, have the disadvantages of not evaluating seed sources during extreme climatic events and naturally occurring pest problems over time. Despite the disadvantages, many families and provenances can be grown in

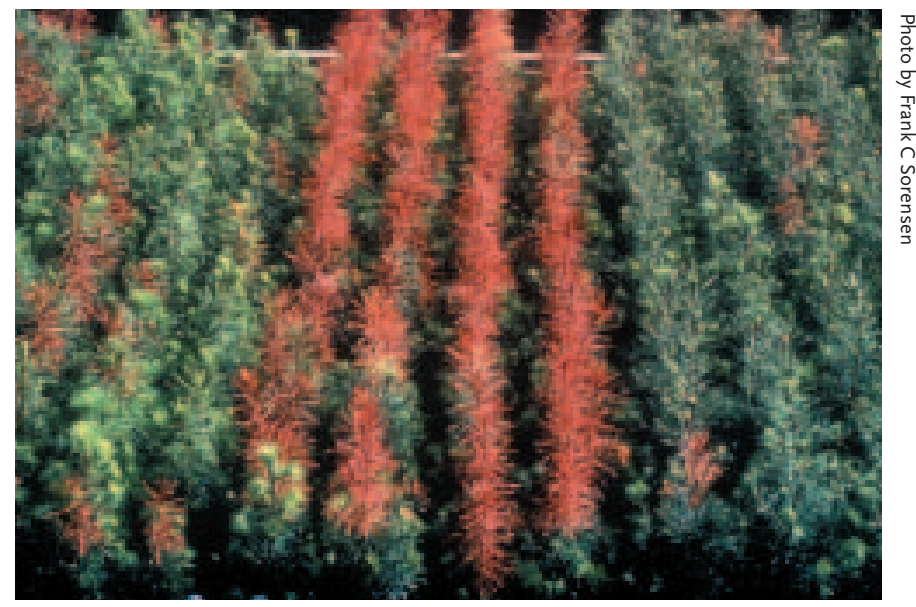

Figure 2. Differences in provenances of Douglas-fir are evident in this common-garden test in Oregon. Each provenance is represented by 4-row plots. Seedlings with brown tops were damaged by frost the previous fall. Differences in time of spring phenology (bud flush) are also apparent among the provenances.

a relatively small space, many traits can be rapidly evaluated because of the small area, and the environment within a single test can be made uniform, allowing less replication and better expression of genetic differentiation.

The goal of these studies is to examine the variation of adaptive traits across the landscape. Adaptive traits are those related to growth rate, phenology, form, cold and drought tolerance, and the like; that is, traits that provide measurable quantitative benefits to a plant in its native environment. Because the seed sources are all grown in a common environment, any difference among them is due to their genetic composition. If the genetic variation is correlated with physiographic or climatic variables of the seed source locations, it provides evidence that the trait has responded to selection pressure and may be of adaptive importance. Over the past $30 \mathrm{y}$, short-term studies have become the research tool of choice for mapping genetic variation in Pacific Northwest conifers.

The early developmental research for studies in conifer genecology was carried out by Campbell (1974a, b, 1979, 1987, 1991) in Oregon and Washington and by Rehfeldt and Wykoff (1981) in the northern Rocky Mountains. Sample areas for these studies were usually intermediate in size, perhaps equivalent to the area included within 1 to 3 national forests ( 1 to 2 degrees range in latitude and longitude) (Rehfeldt 1990, 1994a; Sorensen 1992; Sorensen and Weber 1994), but narrower studies have focused on single watersheds (Campbell 1979) and single coastal islands (Campbell and others 1989). Most of these studies assumed that climate was the driving force behind source-related genetic variation. Because reliable climatic estimates were not available for forested areas, physiography was considered as the best surrogate for climate, and genetic variation was related to physiographic variables. Climatic models have improved in recent years, and more recently variation has been described in terms of 


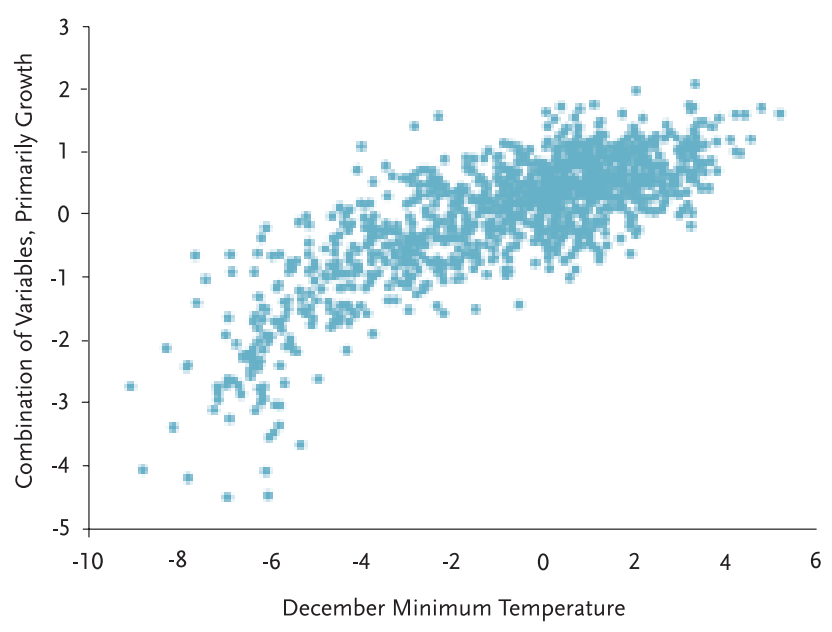

Figure 3. A graph of a composite trait representing growth versus minimum December temperature for families of Douglas-fir in coastal Oregon and Washington.

climatic as well as physiographic variables (Rehfeldt and others 1999; Sorensen and others 2001). Many others have also contributed to this effort; see Randall (1996) and Randall and Berrang (2002) for a more complete listing of relevant research in the Pacific Northwest.

Conifers are predominantly outcrossing with wide pollen distribution. Within their main range, many species also have near-continuous distributions. As expected, given this distribution and reproductive system, the common-garden studies have demonstrated predominantly clinal variation patterns in tree growth, phenology, and cold hardiness. Clinal variation indicates that the observed relation between an environmental variable and a trait is continuous (Figure 3 ). If the steepness of the cline varies across space, it is often referred to as stepped clinal variation (Sorensen and others 1990, 2001). In these cases, steps tend to be associated with taxonomic separations between interfertile taxa (Figure 4). If the observed genetic variation is in distinct groups, it is termed ecotypic variation. Adaptive ecotypic genetic variation should be rare in outcrossing, continuously distributed species and has not been reported in Pacific Northwest conifers. Finally, a species may show little or no source-related variation, even in heterogeneous environments, as in western white pine in northern Idaho (Rehfeldt 1979).

Variation patterns are not consistent among species, among regions, nor among traits. Although Northwest conifers all display clinal variation in all or part of their ranges, the amount and patterns of variation differ for each species. Similarly, the "distance" of separation needed to detect seed source differences differs for diverse groups of conifers sampled in the same region (Table 1; Rehfeldt 1994b). In this case "distance" is defined geographically (meters along an elevational gradient) and climatically (the associated change in number of frost-free days along

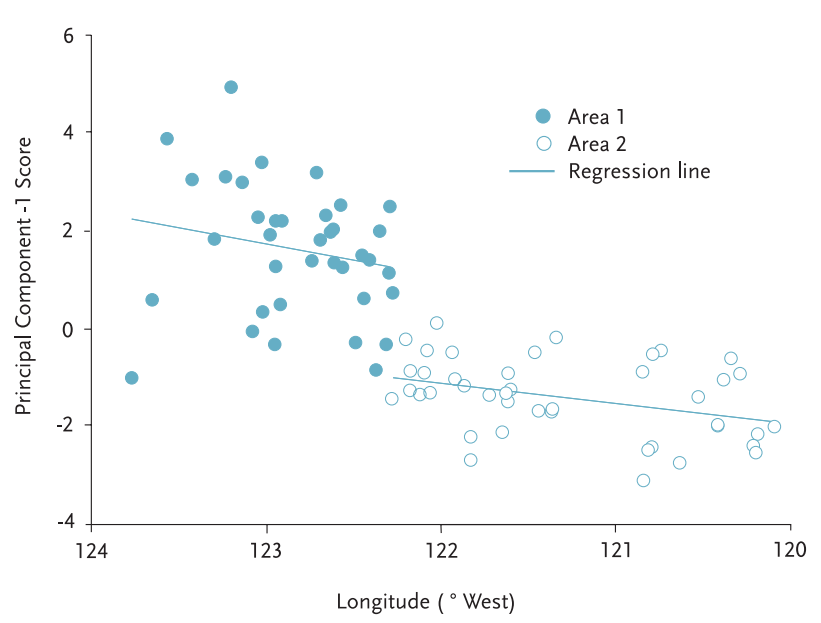

Figure 4. An example of a stepped cline (from Sorensen and others 2001).

Douglas-fir and lodgepole pine as specialists because their populations appear to be adapted to relatively narrow niches. The opposite is true for 2 generalist species, western redcedar (Thuja plicata Donn ex D. Don [Cupressaceae]) and western white pine (Pinus monticola Dougl. ex D.Don [Pinaceae]). Similarly, in the southeastern US, geographic variation is more complex for loblolly pine (Pinus taeda L. [Pinaceae]) than for other southern pines (Schmidtling 2001).

Adaptive genetic gradients can also vary in different parts of the range of the same species. For example, western white pine shows little or no adaptive variation in northern Idaho (Rehfeldt 1979), but shows a greater degree of differentiation along the Cascade Range in western Oregon and Washington (Campbell and Sugano 1989). This pattern of interpopulation differentiation is mirrored at the molecular level, as isozyme variation is greatest in the southern limits of western white pine's distribution and smallest in the northern Rockies (Steinhoff and others 1983). Therefore it is important to recognize that patterns of variation from 2 species in the same genus (for example, Pinus contorta Dougl. ex Loud. and Pinus monticola), or even 2 populations from a single species (for example, Pinus monticola) may be significantly different. For this reason seed zones can rarely be extrapolated to another species or another region of the same species.

\section{Molecular Markers}

Molecular markers may take the form of chemicals (for example, terpenes), proteins or enzymes (for example, allozymes), or nucleic acids (for example, DNA, RNA). Generally speaking, molecular markers are considered to be neutral or nearly neutral because they do not appear to respond to selection, as do adaptive traits. Processes affecting the distribution of variation in molecular markers are migration (movement of alleles among locations), genetic drift (random loss or fixation of alleles), and mutation 


\begin{tabular}{llll} 
Species & $\begin{array}{l}\text { Elevational difference } \\
\text { to find genetic difference }\end{array}$ & $\begin{array}{l}\text { Frost-free days } \\
\text { to find genetic difference }\end{array}$ & Evolutionary mode \\
\hline Douglas-fir & $200 \mathrm{~m}$ & 18 & Specialist \\
\hline Lodgepole pine & $220 \mathrm{~m}$ & 20 & Specialist \\
\hline Engelmann spruce & $370 \mathrm{~m}$ & 33 & Intermediate \\
\hline Ponderosa pine & $420 \mathrm{~m}$ & 38 & Intermediate \\
\hline Western larch & $450 \mathrm{~m}$ & 40 & Generalist \\
\hline Western redcedar & $600 \mathrm{~m}$ & 54 & Generalist \\
\hline Western white pine & none & 90 &
\end{tabular}

(change in the form of an allele). Unless these markers are associated with, or genetically linked to, a trait influenced by selection, variation in molecular markers will be independent of the variation observed in quantitative traits. Numerous studies have compared landscape variation patterns of molecular markers and morphometric traits (reviewed in Karhu and others 1996; McKay and Latta 2002). In conifers, molecular markers typically show far less location variance than adaptive traits when sampled across equivalent scales (Adams and Campbell 1981; Merkle and others 1988; Lagercrantz and Ryman 1990; Karhu and others 1996). Nevertheless, molecular variation may be patterned across the landscape if the sample distribution is extensive (Lagercrantz and Ryman 1990), or if markers exhibit limited dispersal or a small effective population size, as is the case with maternally inherited organelle genomes (Aagaard and others 1995; Latta and Mitton 1999). General reviews of allozyme diversity patterns in plants can be found in Hamrick (1984) and Hamrick and Godt (1990).

Because adaptive and molecular traits respond to different forces (selection versus migration and drift, respectively), one might expect conflicting patterns of differentiation when evaluating both sets of traits in test populations. Indeed, in studies of coniferous and non-coniferous species, little or no concordance has been found between patterns of marker and patterns of morphometric diversity when studied in identical populations (for example, Giles 1984; Spitze 1993; Black-Samuelson and others 1997; Knapp and Rice 1998; McKay and others 2001; Volis and others 2001; McKay and Latta 2002). For this reason, molecular markers are rarely useful in identifying seed transfer zones or breeding zones (see Westfall and Conkle 1992 for an example). Because it is adaptive traits that determine the success of restoration efforts, seed zones established using markers should be considered tentative until confirmed by quantitative traits in a common environment.
Where sharp changes appear in the expression of adaptive traits, where clines are exceptionally steep, or where questions arise about migrational history, molecular markers are useful in determining whether the root cause is a steep environmental gradient or the joining and introgression of formerly separated populations (Li and Adams 1989; Aagaard and others 1995; Latta and Mitton 1999; Sorensen and others 2001). Molecular markers are also valuable tools for providing information about mating systems and gene dispersal (Adams 1992), the importance of random processes in the geographic structure of populations (Adams and Campbell 1981), and the interrelationship between population structure and genetic variability (Yeh and Layton 1979).

\section{DEVELOPING SEED TRANSFER GUIDELINES}

Simply having data on genetic variation is of little help to the land manager. Land managers need to know the amount of variation among populations relative to the variation within populations, and if the population variance is patterned in such a way that it can be reduced by suitable seed-use zones. The general process for developing conifer seed-transfer guidelines in the Pacific Northwest from common-garden studies is presented below.

1 A working sample range is determined, based on administrative or on "seed-need" criteria.

2 Seeds are collected from many sources. The collections should be evenly distributed, with an effort to sample both common and extreme environments. Collections are typically made from single trees but may be bulked collections. At a subset of locations, collections are made 
from two or more individual trees (and kept separate by family) so that genetic variation within populations can be accurately estimated.

3 Seeds are sown in a common environment using a statistically valid design (for example, randomized complete block). Raised nursery beds are often used because of their environmental uniformity and their convenience when measuring small plants.

4 A variety of adaptive traits are measured over 2 or $3 y$ in conifers. Traits typically include germination rate, growth and growth rate, phenology (bud burst and bud set dates), cold hardiness, and plant form (shoot-to-root ratio, height-to-diameter ratio). In non-conifer species, additional significant traits might include ploidy level, key morphological traits (floral, leaf, phyllotaxy), and relevant ecophysiological traits (for example, stomatal conductance or micronutrient concentrations).

5 Analyses are done to determine which traits have statistically significant differences among seed-source locations.

6 For traits that differ by seed source, regression is used to test for correlations with physiographic or climatic gradients. Figure 3 shows an example of how natural selection has established a curvilinear cline where faster growth is associated with sites that have warmer minimum December temperatures. Figure 3 shows a gradient with a sharp longitudinal break in a trait cluster associated with phenology.

7 Variation within a seed source is estimated to determine the amount of overlap among different populations along a gradient. The distribution of adaptive traits is assumed to correspond to the environmental conditions at the population's location. Therefore, the greater the overlap, the higher the probability that seed from one site will be adapted at the other site. A hypothetical situation is shown (Figure 5), where the distribution of growth data from a common-garden study is plotted for 3 sites along an elevational gradient of seed origin. Considerable overlap appears between the populations originating from elevations of 500 and $600 \mathrm{~m}$. Conversely, very little overlap appears between the populations from 250 and $600 \mathrm{~m}$. One would therefore conclude that seed transfer between elevations of 500 and $600 \mathrm{~m}$ would be relatively safe, but moving seed from a 250 -m elevation source to an elevation of $600 \mathrm{~m}$ could lead to serious maladaption.

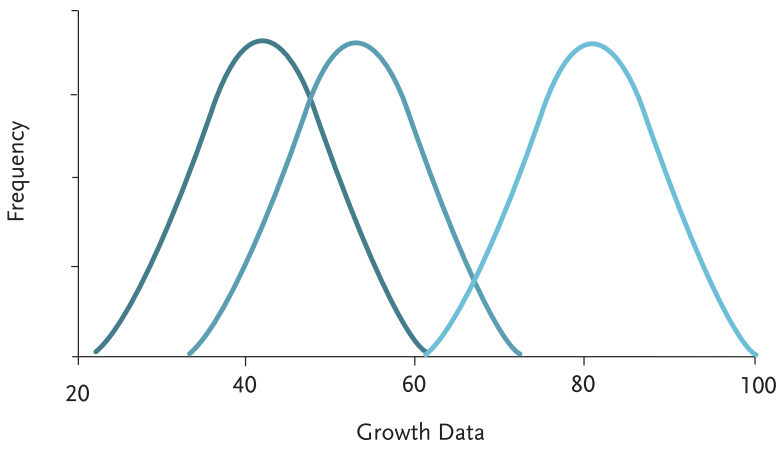

- Population from $600 \mathrm{~m}$ elevation Population from 250 m elevation

Figure 5. A hypothetical demonstration showing the distribution of "growth" for 3 seed sources along an elevational gradient.

\section{Adaptation versus Productivity}

This model of delineating seed zones assumes that "local is best," meaning that local seed is adapted and is most vigorous in the long run. Non-local sources may possibly be better adapted to a site if climate or environment has changed faster than adaptive traits have evolved through natural selection. In addition, if populations are highly discontinuous but disperse over great distances, the immigrant population that gave rise to resident populations may have been less optimal than other populations of the species. Without test data that shows the relative long-term performance of different seed sources, it is impossible to determine whether local or non-local sources are better adapted to a specific site. In forestry the "local is best" assumption has been shown for a number of species, although non-local seed is used by forest managers to improve productivity. One example has been with loblolly pine in the southeastern US. Growth rate on more northern sites within the Southeast has been increased by utilizing more southern, faster-growing populations. The general recommendation is to restrict seed movement to a single USDA plant hardiness zone from its source (Schmidtling 2001). These ratings are based on average annual minimum temperature, delineated in $5^{\circ} \mathrm{F}$ units.

\section{RECOMMENDATIONS FOR FOREST TREE SEED ZONES IN THE PACIFIC NORTHWEST}

Genecological research over the past few decades, using common-garden studies, has been used to revise and expand the original seed zones that were based on field evaluation of topography, climate, and vegetation (Randall 1996; Randall and Berrang 2002). Enlargement in western Oregon and Washington has primarily been in latitude because winter minimum temperatures are mostly associated with elevation. Winter min- 

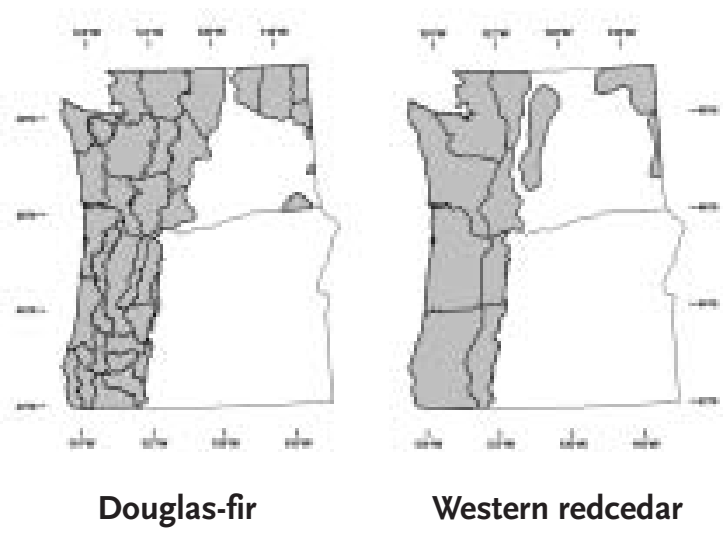

Figure 6. Revised seed zones for Douglas-fir and western redcedar (from Randall 1996; Randall and Berrang 2002).

imum temperature is an important limiting factor for many species and is used to delineate seed zones in horticulture (USDA 1990) and for southern pines (Schmidtling 2001).

Because genetic variation patterns differ by species and location, seed-zone sizes differ by species and region. Revised seed zones for Douglas-fir (a specialist species) and western redcedar (a generalist) are shown in Figure 5. The zones are further delineated by elevation bands, with Douglas-fir bands set at approxi-

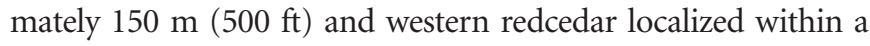
single band or two at most. As evident from Figure 6, western redcedar seed can be transferred great distances without maladaptation, but more restrictions have been placed on Douglasfir seed transfer to minimize maladaptation.

Seed zones are a convenient way to control risks associated with seed movement, but variation across the landscape is rarely confined to discrete zones. In this region, seed zone delineations are artificial constructs for administrative and seed-inventory convenience that lead to increased risks (increasing seed-zone size) or decreased risks (smaller-thannecessary seed zones) from seed transfer depending on the situation. For example, seed collected near the edge of a zone can be used throughout the zone of collection, but it is probably better adapted to part of the neighboring zone than to the far side of its own zone. Discrete zones also fail to consider the recurrence of similar genotypes in similar environments separated by dissimilar environments. Campbell (1974a) laid the groundwork for both a geographically continuous model and a climate-based model to deal with the recurrence problem. An example of a seed-transfer equation for geographically continuous variation is in Sorensen and Weber (1994). Because recurrence is common in the northern Rocky Mountains, Monserud (1990) developed an "expert system" that uses GIS to map ecologically compatible sites for ponderosa pine in part of the Upper Colorado River Basin. Parker (1992) developed a "focal point" seed-zone model that uses climatic data from the planting site in conjunction with GIS to map areas similar to the planting site. The greater the similarity between seed collection and planting environments, the better the chance of well-adapted regeneration. This assumes natural selection is relatively stronger than both gene flow and drift effects for the seed transfer populations.

\section{CONCLUSIONS AND IMPLICATIONS}

Conifer seed transfer guidelines have been primarily developed from common-garden nursery research and these procedures (sampling, traits observed, analysis, application) have been refined over many decades. The delineation of zones based on these procedures works well in managing artificial regeneration of important commercial forest species in environmentally complex regions. Also valuable to managers is the fact that acceptable risk (and zone size) can be altered to fit diverse (and sometimes contrasting) needs, such as conservation or production.

Will guidelines based on common-garden studies work as well for native shrubs, grasses, and herbs? Conifers are longlived, outcrossing plants that lack ploidy level variation and that frequently show a wide habitat range and large contiguous distributions. In contrast, grasses, herbs, and shrubs show far greater variation in each of these attributes, spanning the range of annual to perennial, obligately outcrossing to selfing to apomictic, diploid to highly polyploid, and wide-ranging to narrowly endemic. Most important, their taxonomic complexity almost guarantees that generalizations made from one taxonomic group (for example, selfing or apomictic polyploid annual grasses like Poa secunda J. Presl [Poaceae]) are unlikely to be useful in unrelated taxa (for example, self-incompatible diploid shrubs like Purshia tridentata (Pursh) DC [Rosaceae]).

Adaptive genetic variation is commonplace in native plant species, but most studies have demonstrated ecotypic, rather than clinal, variation patterns (for example, Turesson 1922, 1930; Snaydon and Davies 1972; Abbott 1976; van Tienderen and van der Toorn 1991; and a summary by Meyer and Monsen 1993). We suspect the primary reason ecotypic variation is frequently found is because these studies have examined too few populations to accurately identify clinal variation.

Because adaptive variation is commonplace, land managers should consider using seed movement guidelines when using untested plant material. One option may be to use forest tree seed zones if available. Ecoregions could also be used as surrogate seed zones until research data are available. Ecoregions define areas within which biotic, abiotic, terrestrial, and aquatic capacities and potentials are similar (McMahon and others 2001). Tools are also available to map areas with similar environments so that one can limit seed to areas that have similar climates to the planting site. 
Because most restoration species are small and have short life spans, the restoration community has the opportunity to use both provenance trials and common-garden studies to examine the genetic variation patterns of adaptive variation. A first step in determining seed movement guidelines for a given species could be to establish short-term provenance trials of 30 or more seed sources to examine broadscale genetic differences. These seed sources should cover the range of a species and attempt to sample each ecoregion in which it occurs. For species showing significant source variation in traits that could be adaptive, more finescale genecology studies could be established along the lines used in forest trees.

A variety of random factors may well be more important contributors to the genetic variation patterns in these species than in conifers; these include genetic drift in small populations and introgression from distinct populations or related species. On the other hand, seed traits (for example, dormancy, viability), maternal fertility, and overall reproductive success may play a far more important role in maintaining healthy populations of native (non-conifer) species than in artificially regenerated conifers. Thus, even though random factors may be present, selection and adaptation of fitness traits to environmental heterogeneity should still be important. For example, site disturbance (logging, erosion, fire, and so on) and fragmentation may affect native (non-conifer) populations by reducing gene flow and population size, and thus promote the chances that random drift coupled with selection will together hasten genetic differentiation among populations.

The common-garden procedure has recently been used with a relatively short-lived perennial grass (blue wildrye; Elymus glaucus Buckley [Poaceae]) in the Blue Mountains of Oregon and 3 native grasses in the Plumas National Forest of California. The results from the Blue Mountains study indicated both stepped clinal and clinal variation of adaptive traits (Erickson and others forthcoming). Although some of the spatial stratifications such as watersheds and vegetation and edaphic classifications could be used in delineating the seed-use zones, the grouping of classes into seed zones was dependent on common-garden test results. A priori grouping did not fit the adaptive pattern of variation. Commongarden studies of California native grasses have also shown clinal variation and seed zones were mostly a function of being on the east or west side of the Sierra Nevada crest, along with broad elevation bands (Kitzmiller and Hanson 2003). These findings suggest that the common-garden approach may be useful for guiding seed transfer of important restoration species.

\section{ACNOWLEDGMENTS}

The authors thank Jim Hamlin, Vicky Erickson, Paul Anderson, Martha Brookes, and 2 anonymous reviewers for their
Aagaard JE, Vollmer SS, Sorensen FC, Strauss SH. 1995. Mitochondrial DNA products among RAPD profiles are frequent and strongly differentiated between races of Douglas-fir. Molecular Ecology 4:441-447.

Abbott RJ. 1976. Variation with common groundsel, Senecio vulgaris L. I. Genetic response to spatial variations of the environment. New Phytologist 76:153-164.

Adams WT. 1992. Gene dispersal within forest tree populations. New Forests 6:217-240.

Adams WT, Campbell RK. 1981. Genetic adaptation and source specificity. In: Hobbs SD, Helgerson OT, editors. Reforestation of skeletal soils; 1981 Nov 17-19; Medford, Oregon. Corvallis (OR): Forest Research Laboratory, Oregon State University. p 78-85.

Balduman LM, Aitken SN, Harmon M, Adams WT. 1999. Genetic variation in cold hardiness of Douglas-fir in relation to parent tree environment. Canadian Journal of Forest Research 29:62-72.

Black-Samuelson S, Eriksson G, Gustafsson L, Gustafsson P. 1997. RAPD and morphological analysis of the rare plant species Vicia pisiformis (Fabaceae). Biological Journal of the Linnean Society 61:325-343.

Booth DT, Jones TA. 2001. Plants for ecological restoration: a foundation and a philosophy for the future. Native Plants Journal 2:12-20.

Burdon RD, Low CB. 1991. Performance of Pinus ponderosa and Pinus jeffreyi provenances in New Zealand. Canadian Journal of Forest Research 21:1401-1414.

Campbell RK. 1974a. A provenance-transfer model for boreal regions. Norsk Institutt for Skogforskning 31:544-566.

Campbell RK. 1974b. Use of phenology for examining provenance transfers in reforestation of Douglas-fir. Journal of Applied Ecology 11:1069-1080.

Campbell RK. 1979. Genecology of Douglas-fir in a watershed in the Oregon Cascades. Ecology 60:1036-1050.

Campbell RK. 1987. Biographical distribution limits of Douglas-fir in southwest Oregon. Forest Ecology and Management 18:1-34.

Campbell RK. 1991. Soils, seed-zone maps, and physiography: guidelines for seed transfer of Douglas-fir in southwestern Oregon. Forest Science 37:973-986.

Campbell RK, Sugano AI. 1989. Seed zones and breeding zones for white pine in the Cascade Range of Washington and Oregon. Portland (OR): USDA Forest Service, Pacific Northwest Research Station. Research Paper PNW-RP-407.

Campbell RK, Pawuk WA, Harris AS. 1989. Microgeographic genetic variation of Sitka spruce in southeastern Alaska. Canadian Journal of Forest Research 19:1004-1013.

Cunningham RA. 1975. Provisional tree and shrub zones for the Great Plains. Fort Collins (CO): USDA Forest Service, Rocky Mountain Forest and Range Experiment Station. Research Paper RM-150.

Duffield JW. 1956. Damage to western Washington forests from November 1955 cold wave. Portland (OR): USDA Forest Service, Pacific Northwest Forest and Range Experiment Station. Research Note 129.

Erickson VJ, Mandel NL, Sorensen FC. Landscape patterns of phenotypic variation and population structuring in a selfing grass, Elymus glaucus (blue wildrye). Canadian Journal of Botany (forthcoming). 
Giles BE. 1984. A comparison between quantitative and biochemical variation in the wild barley Hordeum murinum. Evolution 38:34-41.

Hamrick JL. 1984. The distribution of genetic variation within and among natural plant populations. In: Schonewald-Cox CM, Chambers SM, MacBryde B, Thomas WL, editors. Genetics and conservation. Menlo Park (CA): The Benjamin/Cummins Publishing Co Inc.

Hamrick JL, Godt MJW. 1990. Allozyme diversity in plant species. In: Brown AHD, Clegg MT, Kahler AL, Weir BS, editors. Plant population genetics, breeding, and genetic resources. Sunderland (MA): Sinauer. p 43-63.

Hoff RJ. 1988. Susceptibility of ponderosa pine to the needle cast fungus Lophodermium baculiferum. Ogden (UT): USDA Forest Service, Intermountain Research Station. Research Paper INT-386.

Hufford KM, Mazer SJ. 2003. Plant ecotypes: genetic differentiation in the age of ecological restoration. Trends in Ecology and Evolution 18:147-155.

Illingworth K, Szalkai A. 1993. Summary. In: Albricht M, editor. British Columbia interior tree improvement council second progress report 1985-1990. Victoria (BC): British Columbia Ministry of Forests. 52 p.

[ITIS] Integrated Taxonomic Information System. 2002. Biological names (online database). URL: http://www.tis.usda.gov (accessed 24 Aug 2004).

Karhu A, Hurme P, Karjalainen M, Karvonen P, Kärkkäinen K, Neale D, Savolainen O. 1996. Do molecular markers reflect patterns of differentiation in adaptive traits in conifers? Theoretical and Applied Genetics 93:216-221.

Kitzmiller J, Hanson L. 2003. California native grasses genecological studies. Portland (OR): Ecological genetics and native plant material development workshop. 2003 Nov 2-5. URL: ftp://ftp2.fs.fed.us/incoming/ r6/ro/native_plants (accessed 24 Aug 2004).

Kleinschmit J, Svolba J, Rau H-M, Weisgerber H. 1996. The IUFRO Abies grandis provenance experiment in Germany. Silvae Genetica 45:311-317.

Knapp EE, Rice KJ. 1998. Comparison of isozymes and quantitative traits for evaluating patterns of genetic variation in purple needle grass (Nassella pulchra). Conservation Biology 12:1031-1041.

Lagercrantz U, Ryman N. 1990. Genetic structure of Norway spruce (Picea abies): concordance of morphological and allozymic variation. Evolution 44:38-53.

Langlet O. 1936. Studier över tallen fysiologiska variabilitet och dess samband med klimatet. Ett bitrag till kännedomen om tallens ecotyper. Meddelingen från Statens Skogsförsökanstalt 29:219-420.

Latta RG, Mitton JB. 1999. Historical separation and present gene flow through a zone of secondary contact in ponderosa pine. Evolution 53:769-776.

Lesica P, Allendorf FW. 1999. Ecological genetics and the restoration of plant communities: mix or match? Restoration Ecology 7:42-50.

Li P, Adams WT. 1989. Range-wide patterns of allozyme variation in Douglas-fir (Pseudotsuga menziesii). Canadian Journal of Forest Research 19:149-161.

McKay JK, Latta RG. 2002. Adaptive population divergence: markers, QTL and traits. Trends in Ecology and Evolution 17:285-291.

McKay JK, Bishop JG, Lin J-Z, Richards JH, Sala A, Stranger B, Mitchell-Olds T. 2001. Local adaptation despite absence of marker diversity in the rare
Sapphire Rockcress. Proceedings of the Royal Society of London 268:1715-1721.

McMahon G, Gregonis SM, Waltman SW, Omernik JM, Thorson TD, Freeouf JA, Rorick AH, Keys JE. 2001. Developing a spatial framework of common ecological regions for the conterminous US. Environmental Management 28:293-316.

Merkle SA, Adams WT, Campbell RK. 1988. Multivariate analysis of allozyme variation patterns in coastal Douglas-fir from southwest Oregon. Canadian Journal of Forest Research 18:181-187.

Meyer SE, Monsen SB. 1993. Genetic considerations in propagating native shrubs, forbs, and grasses from seed. In: Landis TD, technical coordinator. Proceedings: Western Forest Nursery Association. Fort Collins (CO): USDA Forest Service, Rocky Mountain Forest and Range Experiment Station. General Technical Report GTR-RM-221. p 47-54.

Monserud RA. 1990. An expert system for determining compatible seedtransfer locations. Al Applications 4:44-50.

Munger TT, Morris WG. 1937. Growth of Douglas fir trees of known seed source. Washington (DC): United States Department of Agriculture. Technical Bulletin 537. 40 p.

Parker WH. 1992. Focal point seed zones: site-specific seed zone delineation using geographic information systems. Canadian Journal of Forest Research 22:267-271.

Randall WK. 1996. Forest tree seed zones for western Oregon. Salem (OR): Oregon Department of Forestry.

Randall WK, Berrang P. 2002. Washington tree seed transfer zones. Olympia (WA): Washington Department of Natural Resources.

Read RA. 1971. Browsing preference by jackrabbits in a ponderosa pine provenance plantation. Fort Collins (CO): USDA Forest Service, Rocky Mountain Forest and Range Experiment Station. Research Note RM-186. 4 p.

Read RA, Sprackling JA. 1981. Hail damage variation by seed source in a ponderosa pine plantation. Fort Collins (CO): USDA Forest Service, Rocky Mountain Forest and Range Experiment Station. Research Note RM-410. 6 p.

Rehfeldt GE. 1979. Ecotypic differentiation in populations of Pinus monticola in north Idaho-myth or reality? American Naturalist 114:627-636.

Rehfeldt GE. 1990. Genetic differentiation among populations of Pinus ponderosa from the upper Colorado River Basin. Botanical Gazette 151:125-135.

Rehfeldt GE. 1994a. Adaptation of Picea engelmannii populations to the heterogeneous environments of the Intermountain West. Canadian Journal of Botany 72:1197-1208.

Rehfeldt GE. 1994b. Evolutionary genetics, the biological species, and the ecology of interior cedar-hemlock forests. In: Proceedings of interior cedar-hemlock-white pine forests: ecology and management; 1993 Mar 2-4; Spokane, Washington. Pullman (WA): Washington State University. p 91-100.

Rehfeldt GE, Wykoff WR. 1981. Periodicity in shoot elongation among populations of Pinus contorta from the northern Rocky Mountains. Annals of Botany 48:371-377.

Rehfeldt GE, Ying CY, Spittlehouse DL, Hamilton DA Jr. 1999. Genetic responses to climate in Pinus contorta: niche breadth, climate change, and reforestation. Ecological Monographs 69:375-407. 
Schmidtling RC. 2001. Southern pine seed sources. Asheville (NC): USDA Forest Service, Southern Forest Research Station. General Technical Report SRS-44.

Schott PK. 1904. Pinus sylvestris L., die gemeine Kiefer. Beiträge zur Systematik und Provenienzfrage mit besonderer Berücksichtigung des in Deutschland in den Handel kommenden Samens. Forstwissenschaftliches Centralblatt 26:123-141, 307-324, 436-449, 515-536, 587-606.

Silen RR. 1995. Personal communication. Corvallis (OR): USDA Forest Service, Pacific Northwest Research Station. Supervisory Research Geneticist.

Silen RR, Mandel NL. 1983. Clinal genetic growth variation within two Douglas-fir breeding zones. Journal of Forestry 81:216-220.

Snaydon RW, Davies MS. 1972. Rapid population differentiation in a mosaic environment. II. Morphological variation in Anthoxanthum odoratum. Evolution 26:390-405.

Sorensen FC, Weber JC. 1994. Genetic variation and seed transfer guidelines for ponderosa pine in the Ochoco and Malheur National Forests of central Oregon. Portland (OR): USDA Forest Service, Pacific Northwest Research Station. Research Paper PNW-RP-468.

Sorensen FC. 1992. Genetic variation and seed transfer guidelines for lodgepole pine in central Oregon. Portland (OR): USDA Forest Service, Pacific Northwest Research Station. Research Paper PNW-RP-453.

Sorensen FC, Campbell RK, Franklin JF. 1990. Geographic variation in growth and phenology of seedlings of the Abies procera/A. magnifica complex. Forest Ecology and Management 36:205-232.

Sorensen FC, Mandel NL, Aagaard JE. 2001. Role of selection versus historical isolation in racial differentiation of ponderosa pine in southern Oregon: an investigation of alternative hypotheses. Canadian Journal of Forest Research 31:1127-1139.

Spitze K. 1993. Population structure in Daphnia obtusa: quantitative genetic and allozymic variation. Genetics 135:367-374.

Squillace AE, Silen RR. 1962. Racial variation in ponderosa pine. Forest Science Monograph 2:1-27.

Steinhoff RI, Joyce DG, Fins L. 1983. Isozyme variation in Pinus monticola. Canadian Journal of Forest Research 13:1122-1132.

Tree Seed Zone Map. 1973. Portland (OR): USDA Forest Service in cooperation with the Western Forest Tree Seed Council.

Turesson G. 1922. The genotypical response of plant species to the habitat. Hereditas 3:211-350.

Turesson G. 1930. The selective effect of climate upon the plant species. Hereditas 14:99-152.

[USDA] United States Department of Agriculture. 1990. USDA plant hardiness zone map. USDA Agricultural Research Service. Miscellaneous Publication No. 1475.

van Tienderen PH, van der Toorn J. 1991. Genetic differentiation between populations of Plantago lanceolata. I. Local adaptation in three contrasting habitats. Journal of Ecology 79:27-42.

Volis S, Yakubov B, Shulgina I, Ward D, Zur V, Mendlinger S. 2001. Tests for adaptive RAPD variation in population genetic structure of wild barley, Hordeum spontaneum Koch. Biological Journal of the Linnean Society 74:289-303.

Wakeley PC, Bercaw TE. 1965. Loblolly pine provenance test. Journal of Forestry 63(3):168-174.
Westfall RD, Conkle MT. 1992. Allozyme markers in breeding zone designation. New Forests 6:279-309.

White TL, Ching KK. 1985. Provenance study of Douglas-fir in the Pacific Northwest region IV. Field performance at age 25 years. Silvae Genetica 34:84-90.

Xie CY, Ying CC. 1994. Adaptedness of noble fir (Abies procera Rehd.) beyond its northern limit. Forest Science 40:412-428.

Yeh FC, Layton C. 1979. The organization of genetic variability in central and marginal populations of lodgepole pine, Pinus contorta ssp. latifolia. Canadian Journal of Genetics and Cytology 21:487-503.

Ying CC. 1997. Effects of site, provenance, provenance and site interaction in Sitka spruce in coastal British Columbia. Forest Genetics 4:99-112.

Ying CC, Hunt RS. 1987. Stability of resistance among Pinus contorta provenances to Lophodermella concolor needle cast. Canadian Journal of Forest Research 17:1596-1601.

Zon R. 1913. Effect of source of seed upon the growth of Douglas fir. Forestry Quarterly 11:499-502.

\section{AUTHOR INFORMATION}

Randy Johnson

Research Geneticist

randyjohnson@fs.fed.us

Frank C Sorensen

Research Geneticist

J Bradley St Clair

Research Geneticist

Richard C Cronn

Research Geneticist

USDA Forest Service

Pacific Northwest Research Station

Forestry Sciences Laboratory

3200 SW Jefferson Way

Corvallis OR, 97331-4401 